\title{
EVALUASI TINGKAT KECENDERUNGAN PENERAPAN TEMA/KONSEP ARSITEKTUR NUSANTARA DALAM SKRIPSI ARSITEKTUR TAHUN AKADEMIK 2007-2011
}

\author{
Rinawati P. Handajani, Damayanti Asikin, \\ Sigmawan T Pamungkas, Agung Murti Nugroho, Wulan Astrini, ST., M.Ds. \\ Jurusan Arsitektur, Fakultas Teknik, Universitas Brawijaya \\ rinawatinoor@yahoo.com
}

\begin{abstract}
ABSTRAK
Penelitian ini dimaksudkan untuk mengetahui tingkat kecenderungan mahasiswa Jurusan Arsitektur FTUB dalam menerapkan arsitektur nusantara di tugas akhirnya serta untuk mengetahui ragam konsep arsitektur nusantara yang telah diterapkan oleh lulusan Jurusan Arsitektur FTUB. Adapun batasan penelitian ini yaitu tugas akhir mahasiswa Jurusan Arsitektur FTUB dalam kurun waktu 5 tahun terakhir (2007-2011). Indikator evaluasi lebih pada tingkat kecenderungan penerapan tema/konsep arsitektur nusantara, dibatasi pada tema, isue, pendekatan serta hasil akhir.

Manfaat yang diberikan dari penelitian ini khususnya bagi Jurusan Arsitektur FTUB, antara lain yaitu untuk mengevaluasi keberhasilan kurikulum dalam meningkatkan kompetensi lulusan sesuai dengan visi dan misi jurusan, sebagai pedoman bagi perbaikan maupun pengembangan kurikulum yang berbasis arsitektur nusantara, sebagai pedoman dalam pengembangan muatan materi yang diemban oleh setiap laboratorium. Diharapkan juga dapat memberikan manfaat bagi jurusan-jurusan lainnya di Fakultas Teknik Universitas Brawijaya untuk mengevaluasi keberhasilan kurikulum yang diterapkan guna meningkatkan kompetensi lulusannya.
\end{abstract}

Kata kunci: Skripsi, tingkat kecenderungan, arsitektur nusantara

\section{ABSTRACT}

This study aimed to determine the level of student tendencies in the Department of Architecture FTUB in impelementing Nusantara Architecture in their final task and to knwo the variety of Nusantara Architecture concept that have been implemented by graduates of Department of Architecture FTUB. The limitation of this study is the final task of students of Department of Architecture FTUB within the last 5 years (2007-2011). Evaluation indicators are tendency level of implementing Nusantara Architecture theme/concept which is confined to the theme, isue, approaches and outcomes.

Benefits provided from this study, especially for Department of Architecture FTUB are to evaluate the success of the curriculum to enhance competency in accordance with the vision and mission of the department, as a guide for the improvement and development of curriculum-based Nusantara Architecture, as a guide in the development of lecturing materials by each laboratory. Besides, it is expected to provide benefits to other departments in the FTUB to evaluate the successful in implementing curriculum to improve the competence of graduates.

Keywords: Final task, tendency level, Nusantara Architecture 


\section{Pendahuluan}

Sesuai dengan visinya, Jurusan Arsitektur FTUB berupaya mengembangkan keilmuan arsitektur nusantara di bidang perencanaan, perancangan, pelaksanaan, pengelolaan, dan penelitian lingkungan binaan yang berkelanjutan dalam lingkup Asia Tenggara. Arsitektur Nusantara merupakan ilmu perancangan lingkungan binaan yang didasarkan pada konsep dan budaya nusantara (kepulauan diantara lautan). Wilayah nusantara terbentang dari negeri-negeri Asia Tenggara daratan, berlanjut ke Aceh sampai dengan kepulauan di Timur Papua; dari Utara ke Selatan mulai dari Kepulauan Jepang sampai kompleks Pulau Rote ( $\underline{w w w .4 a r c h i c u l t r e . c o m}$ ). Arsitektur nusantara memiliki konsep menghargai alam, dimana desain-desain lingkungan binaan (hunian) menerapkan nilai-nilai alami yang diajarkan oleh alam itu sendiri serta budaya/tradisi yang turuntemurun dalam kehidupan masyarakatnya. Bahkan jika ditelusuri lebih jauh lagi, masyarakat nusantara memiliki pemahaman filosofis yang tinggi terhadap alam sekitarnya dan mereka aplikasikan baik dalam desain lingkungan binaannya maupun perilaku seharihari.

Karakter-karakter hunian dalam arsitektur nusantara memiliki kekhasan yang dapat dikembangkan sepanjang masa atau di ranah ke-kini-an (kontemporer), sehingga tetap berjalan selaras dengan era modern yang berkembang saat ini. Dalam arsitektur nusantara, mulai dari jenis material bangunan; bentuk dan ketinggian atap; proporsi bangunan; ornamen/ragam hias; bentuk, ukuran, dan penempatan bukaan; hingga penataan hunian di dalam kawasan, seluruhnya menjunjung tinggi nilai-nilai lokalitas yang menjadikannya ciri khas masing-masing daerah. Di samping itu, adapula budaya nusantara yang berkembang dalam kehidupan dan perilaku masyarakatnya, yaitu budaya gotong royong, kebersamaan, serta kepedulian antar sesama.

Berdasarkan data kurikulum tahun 2007-2011 menunjukkan bahwa telah cukup banyak mahasiswa yang mengambil judul atau tema ke arah arsitektur nusantara, tetapi apakah hanya sebatas judul, tema atau sudah lebih mengarah ke isu, bahkan lebih jauh pada pendekatan dan penerapannya, belum teridentifikasi dengan jelas. Secara garis besar, berdasarkan pengamatan dan penelaahan hasil skripsi, kebanyakan masih pada taraf tataran isue, konsep dan pendekatan dalam menerapkan tema/konsep arsitektur nusantara. Sedangkan yang sampai pada tahap menerapkan dan mentaransformasikan dengan cukup baik pada desain maupun rekomendasi desainnya masih dalam jumlah yang terbatas. Kondisi tersebut menunjukkan bahwa arahan maupun bimbingan kepada mahasiswa peserta skripsi harus terus dilakukan. Bukan hanya dengan tujuan pencapaian misi dan visi jurusan semata, tapi lebih jauh adalah membentuk sarjana yang menjunjung tinggi nilai-nilai lokalitas, yang tetap mengedepankan kebersamaan, serta kepedulian antar sesama, sehingga menjadikan lulusan yang arif dan peduli terhadap alam dan manusia.

\section{Bahan dan Metode}

2.1 Arsitektur Nusantara

Istilah nusantara dipoluperkan oleh Dr. Setiabudi atau Eugene Douwes Dekker (1879-1950) sejak tahun 1920 yang mengambil sumber dari sumpah Palapa Mahapatih Gajah Mada. Arti nusantara adalah gugusan pulau-pulau kecil/ sedang yang terletak diantara dua benua dan dua samudera (Tribinuka, 2008). Arsitektur tradisional memiliki perbedaan dengan arsitektur nusantara. Arsitektur nusantara berkepentingan untuk menunjukkan jatidiri sebuah wilayah geografis (Yudohusodo, 1991). 
Konsepsi arsitektur nusantara yang arif terhadap alam dan manusia menjadikannya sangat penting untuk dilestarikan dan dikembangkan dalam dunia arsitektur Indonesia khususnya dan Asia Tenggara umumnya. Untuk itu, konsep kurikulum di Jurusan Arsitektur FTUB periode 2011-2015 diarahkan ke konsep arsitektur nusantara karena Indonesia di masa depan diperlukan arsitek-arsitek yang mampu mengabdi bagi kepentingan masyarakat secara nyata dengan kualitas proses dan hasil karya yang baik. Oleh karenanya kontekstualisasi dan internasionalisasi pendidikan arsitektur merupakan salah satu alternatif cara yang tepat untuk menghasilkan arsitek-arsitek yang memiliki kepekaan sosial budaya sekaligus berkemampuan rancang bangun yang tinggi; menjadi arsitek yang merakyat dengan kemampuan internasional. Untuk mencapai tujuan dan sasaran ini, sangat diperlukan perencanaan yang matang pada pengembangan kurikulum, termasuk proses belajar-mengajarnya (Purbadi, 2000).

\subsection{Metode Penelitian}

Penelitian ini merupakan penelitian dekskriptif yang dianalisis menggunakan metode kuantitatif. Data primer dalam penelitian ini yaitu tugas akhir mahasiswa Jurusan Arsitektur FTUB dalam kurun waktu 2008-2012 dan target capaian dari kurikulum 2011/2012-2015/2015. Metode pengumpulan data primer yang digunakan dengan pengklasifikasian data berdasar isue, pendekatan dan hasil akhir skripsi arsitektur.

Sampel diambil $50 \%$ dari data mahasiswa peserta skripsi disetiap periode, sebagai bahan analisis untuk melihat kecenderungan penerapan arsitektur nusantara pada skripsi, baik pada tahap judul, isue, pendekatan hingga penerapan.

Data-data tugas akhir mahasiswa Jurusan Arsitektur FTUB diklasifikasikan berdasarkan isue, pendekatan dan hasil akhir. Selanjutnya data tersebut dianalisis secara kuantitatif untuk mengetahui tingkat kecenderungan skripsi arsitektur mahasiswa Jurusan Arsitektur FTUB dalam menerapkan arsitektur nusantara' serta sejauh mana penerapan konsep arsitektur nusantara di dalamnya.

\section{Hasil dan Pembahasan}

\subsection{Parameter Penerapan Arsitektur Nusantara}

Parameter penerapan arsitektur nusantara pada skripsi, antara lain yaitu:

- Kecenderungan judul, bahwa mulai dari judul dapat dilihat arah isi dari skripsi

- Kecenderungan isu, bahwa dari isue dapat dilihat apa latar belakang yang mendasari dan permasalahan yang akan diselesaikan

- Pendekatan, meliputi analisa dan konsep sebagai dasar perancangan

- Penerapan, tahap perancangan dan transformasi konsep ke desain

- Konsistensi, melihat konsistensi pengerjaan dari tahap ke tahap selanjutnnya, khususnya konsistensi kearah arsitektur nusantara

\subsubsection{Kecenderungan Judul}

\section{A. Produk skripsi di tahun 2007}

Mulai tahun 2007 kecenderungan judul yang menerapkan arsitektur nusantara mulai meningkat, dimana penekanan pada aspek ekologis, pemanfaatan material alam, dan aspek kenusantaraan lainnya lebih terlihat. Hal ini dimungkinkan karena pada tahun 2003 sempat ada wacana untuk menetapkan tema kurikulum Arsitektur Nusantara Bahari. 
Tetapi kemudian wacana tersebut tidak berlanjut, dikarenakan banyak aspek yang harus dipertimbangkan lebih dulu, terkait dengan kurikulum, matakuliah, hingga aspek yang lain. Pada kurikulum 2007 tidak ada pembicaraan ke arah tema pada kurikulumnya, sehingga perubahan kurikulum bergulir begitu saja tanpa mengusung tema tertentu pada kurikulumnya. Beberapa judul di tahun 2007 yang mulai menggambarkan kepedulian terhadap alam dan lingkungan, antara lain yaitu:

- "Flower Center" Berkonsep Merangkul Alam sebagai Pusat Promosi dan Pemasaran Tanaman Hias di Batu.

- Kosmologi Marapu dalam Arsitektur di Rumah \& Kampung Adat di Tarung. Waikabubak, Sumba Barat

\section{B. Produk skripsi di tahun 2008}

Di tahun 2008, judul yang mengarah ke aspek kenusantaraan semakin banyak dan berada pada kisaran angka $60 \%$. Beberapa contoh judul tersebut antara lain:

- Adapatasi Selubung Bangunan Terhadap Iklim Tropis pada Rumah Dinas Bercorak Arsitektur Kolonial Belanda di Kompleks Wonolangan Probolinggo.

- Karakteristik Konstruksi Kayu Rumah Tradisional Jawa di Desa Selopamioro

- Pusat Perbelanjaan Modern dan Pasar Tradional dengan Konsep Tropical Garden di Malang

\section{Produk skripsi di tahun 2009}

Puncak berkembangnya judul-judul yang berbasis arsitektur nusantara berkembang pesat di tahun 2009. Judul-judul semakin mengarah pada tema-tema kearifan lokal, arsitektur yang berwawasan lingkungan, dan berkelanjutan hingga arsitektur kenusantaraan. Prosentase judul yang sudah mengarah pada aspek kenusantaraan berkisar 70\%. Peran dosen pembimbing sangat berperan dalam pemahaman dan pemaknaan arsitektur nusantara secara benar. Berikut beberapa judul tugas akhir yang mulai mengarah pada aspek kenusantaraan:

- Nilai Tradisional dalam Konsep Spasial Rumah Tinggal Studi Kasus Gubug Adat Karang Bajo Kecamatan Bayan NTB

- Pengoptimalan Penghawaan Alami Melalui Pengolahan Elemen Bukaan Jendela dan Tritisan Bangunan Rumah Tinggal di Malang

- Bangunan Pusat Pendidikan Lingkungan Hidup di Batu (Menuju Green Architecture)

- Model Green House Komersial dengan Pendekatan Eksplorasi Desain

- Pendekatan Konsep Arsitektur Ekologis pada Bangunan Masjid ( Studi Kasus: Masjid Ibnu Sina Malang)

- Adaptasi Selubung Rumah Kuno Kolonial Belanda Terhadap Iklim Tropis Lembab di Kota Malang

- Penerapan Arsitektur Hijau pada Pengembangan Landing Zone di Kawasan Wisata Paralayang Kota Batu

- Interior Ruang Keluarga dengan Aplikasi Material Eksterior yang Alami pada Perumahan Bertipe Sedang dan Kecil di Kota Malang

- Prinsip Termal Rumah Tradisional Jawa sebagai Dasar Perancangan Perumahan Sederhana (Obyek Kajian: Perumahan Sederhana di Kota Malang)

- Roof Garden Sebagai Penunjang Kualitas Lingkungan dalam Bangunan Perkantoran (Studi Kasus: Kantor Taspen Malang) 
- Interior Ruang Display Galeri Elemen Pembatas Ruang di Malang (Obyek Display: Material Daur Ulang Organik)

- Penerapan Bambu Sebagai Konstruksi Utama pada Bangunan Gedung Sekolah Dasar (Studi Kasus: Desa Tunjungtirto Kecamatan Karangploso Kabupaten Malang)

D. Produk skripsi di tahun 2010 dan 2011

Di tahun 2010 dan 2011, produk skripsi sudah lebih banyak yang mengarah pada arsitektur nusantara. Berikut beberapa judul tugas akhir yang mulai mengarah pada aspek kenusantaraan:

- Konsep Arsitektur Ekologi pada Pondok Pesantren Al Amien Putra di Kabupaten Sumenep

- Galeri Kerajinan Kerang Situbondo (Eksplorasi Material Kerang pada Elemen Interior Ruang Pamer)

- Aplikasi Material Daur Ulang Sampah Gelas Plastik sebagai Bahan Pengisi Komponen Bangunan Puslit

- Bahan Limbah Kerajian Mebel sebagai Elemen Interior pada Pusat Kerajinan Mebel Kota Malang

- Material Daur Ulang Anorganik pada Elemen Interior Galeri Seni Daur Ulang Anorganik di Surabaya

- Penerapan Material Alami pada Pusat Pengembangan Agroteknologi di Pujon

- Konsep Ekowisata pada Taman Wisata Bendungan Wonorejo Tulungagung

- Agroindustri Jeruk di UPT Simpang Arja Barito Kuala, Kalimantan Selatan dengan Konsep Material Lokal

- Fasilitas Pelabuhan Perikanan Pantai Berkonsep Ekologi Teknik di Kawasan Minapolitan Muncar Banyuwangi

- Transformasi Pemukiman Tradisional Suku Sasak dalam Sentra Industri Gerabah Terpadu Banyumulek

Dari keseluruhan judul yang ada, hampir $80 \%$ sudah mengarah pada arsitektur nusantara. Hal ini menunjukkan perkembangan yang cukup baik dalam hal pemilihan topik dan judul skripsi yang mengarah sesuai tema kurikulum. Rata-rata perkembangan kecenderungan judul/tema yang telah mengarah pada arsitektur nusantara dari tahun ke tahun dapat dilihat pada tabel berikut ini.

\section{Tabel 1. Perkembangan Penerapan Arsitekur Nusantara} Pada Judul Skripsi

\begin{tabular}{|c|c|}
\hline TAHUN & TINGKAT PENERAPAN \\
\hline 2007 & 1,48 \\
\hline 2008 & 2,17 \\
\hline 2009 & 3,0 \\
\hline 2010 & 2,9 \\
\hline 2011 & 3,5 \\
\hline
\end{tabular}

Dari data di atas, nampak perkembangan cukup pesat dari tahun 2008 ke tahun 2009. Analisa dari kondisi yang ada, di tahun 2009 suntikan pemahaman tentang arsitektur nusantara memang cukup intens, sehingga banyak sekali mahasiswa mengambil judul-judul 
tersebut, meski ditengarai pemahaman dan pemaknaan tentang arsitektur nusantara tersebut belum terlalu maksimal dipahami, terlebih diterapkan pada pengerjaan skripsinya. Di tahun 2010, mahasiswa mulai mengalami kejenuhan dengan judul-judul tersebut, hal ini mungkin dikarenakan pemahaman yang belum maksimal, mungkin juga kurangnya arahan dari dosen pembimbing, sehingga judul yang muncul hanya pada kisaran itu-itu saja. Diperlukan pemahaman akan keluasan makna arsitektur nusantara, agar judul bisa lebih berkembang dan bervariasi. Tahun 2011, sejalan dengan diberlakukannya kurikulum berbasis arsitektur nusantara, perkembangan judul-judul arsitektur nusantara telah sangat baik, lepas dari konsistensi dan penerapan pada perancangannya, apapun mahasiswa telah mencoba ikut menggali dan memaknai arsitektur nusantara.

\subsubsection{Kecenderungan Isue}

Kecenderungan isue cenderung masih sejalan dengan judul. Mulai tahun 2007 isue akan penyelamatan lingkungan, kearifan lokal maupun aspek kenusantaraan mulai banyak bermunculan. Rata-rata perkembangan kecenderungan isue yang telah mengarah pada arsitektur nusantara dari tahun ke tahun dapat dilihat pada tabel berikut ini.

Tabel 2. Perkembangan Penerapan Arsitekur Nusantara Pada Isue Skripsi

\begin{tabular}{|c|c|}
\hline TAHUN & TINGKAT PENERAPAN \\
\hline 2007 & 1,36 \\
\hline 2008 & 2,01 \\
\hline 2009 & 3,27 \\
\hline 2010 & 2,8 \\
\hline 2011 & 3,15 \\
\hline
\end{tabular}

(Sumber: Hasil analisis, 2012)

Dari data di atas, nampaknya kecenderungan isue berjalan linier sejajar dengan perkembangan kecenderungan judul, nampak perkembangan cukup pesat dari tahun 2008 ke 2009. Meski di tahun 2010 ada kemunduran pada penerapan isue, yang pasti sejalan dengan kejenuhan pada kecenderungan judul. Tetapi di tahun 2011 mulai nampak perkembangan isue-isue arsitektur nusantara dengan sangat baik. Hal ini ditengarai pada pemahaman akan keluasan makna arsitektur nusantara sudah lebih baik, karena isue lebih berkembang dan bervariasi.

\subsubsection{Tahap Pendekatan, Analisa, dan Konsep Perancangan}

Untuk mewujudkan desain, proses perancangan umumnya dibagi menjadi tiga tahapan mulai dari awal yaitu pra rencana, perancangan, dan pasca rancangan. Pada tahap pra-rencana, diawali dengan penelitian dan analisis karakteristik dari bangunan yang dirancang dan lingkungan alam sekitarnya. Penghayatan dan pemahaman kondisi dan karakteristik tapak, yaitu untuk menjajagi tapak yang bisa digali untuk dimanfaatkan bagi perancangan bangunan, hubungan tapak dengan kawasan disekitarnya yang lebih luas dari segi fisik, sosial dan budaya. Konsep perancangan pembelajaran ditujukan untuk melatih dan membaca kondisi alam serta semua ekosistem di dalamnya yang berkaitan dengan manusia dan bangunan seperti kondisi fisik, tapak, geografi, landsekap, sosial dan budaya masyarakat, biota yang terkandung pada tapak, termasuk fauna dan vegetasi, iklim pada skala mikro maupun makro, sejarah budaya dan semua sumber daya setempat yang ada. Termasuk penghayatan tentang arsitektur nusantara, bahwa kekayaan arsitektur nusantara 
mengandung konsep-konsep ekologi sederhana, tepat guna, ramah lingkungan, namun tetap mengutamakan fungsi dan syarat sebuah bangunan. Keamanan, kenyamanan, tuntutan kebutuhan ruang menjadi faktor utama dalam penentuan lokasi bangunan dengan tetap memperhatikan aspek religi, kepercayaan masyarakat setempat, hingga material lokal yang biasa digunakan.

Di tahun 2007 analisis atau pendekatan yang paling sering dilakukan mahasiswa adalah pada analisa tapak, dimana bangunan tidak dapat dipandang sebagai satu bangunan yang berdiri sendiri di atas sebidang tapak, tetapi bangunan dilihat sebagai bagian dari tapak itu dan bangunan lain disekitarnya. Analisis tapak yang dilakukan hampir selalu mempertimbangkan aspek iklim setempat, juga bagaimana rancangan bangunan nantinya tidak menimbulkan dampak negatif pada sekitarnya baik alam, social, dan budaya. Berikut adalah contoh analisa tapak yang dilakukan mahasiswa skripsi di tahun 2007:
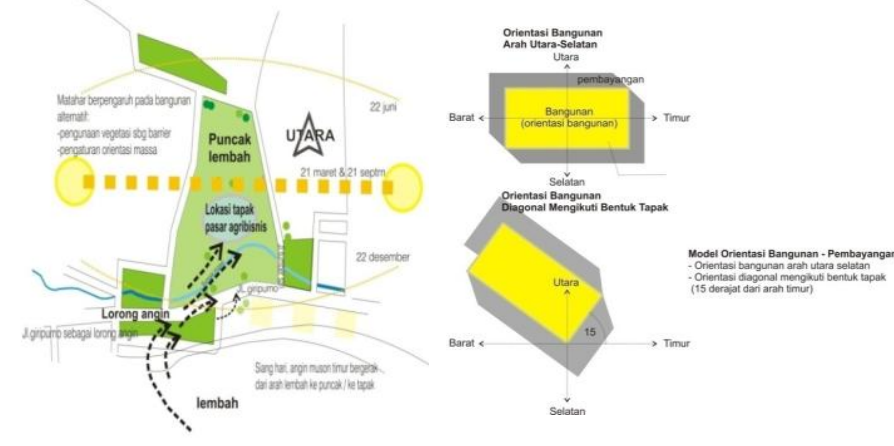

Gambar 1

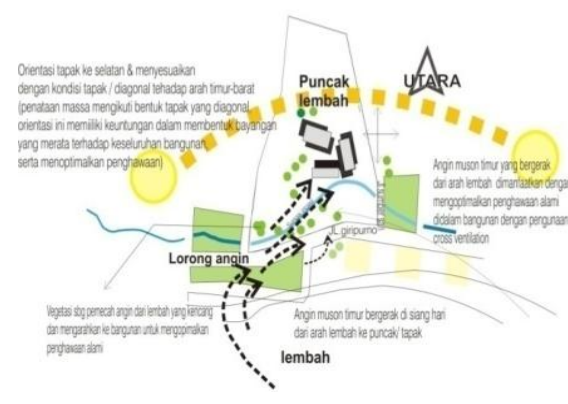

Contoh Pendekatan Tapak dan Lingkungan

(Sumber: Susanto, Edwin Dwi, 2008)

Di tahun 2008 kecenderungan judul yang bertemakan arsitektur nusantara terlihat pada aspek ekologis, pemanfaatan material alam, dan aspek lain kenusantaraan. Hal ini diikuti juga dengan perkembangan pendekatan yang dilakukan, pendekatan ke arah pengkondisian, pemanfaatan dan sikap arif terhadap alam dan lingkungan semakin membaik sebagaiman ditunjukkan dalam oleh data hasil analisis dalam tabel 3. Lonjakan terjadi pada tahun 2009, dimana dari data yang ada lonjakan angka nampak sangat baik dalam hal pendekatannya, meski mungkin masih diragukan pada tahap konsistensi dalam penerapannya. Meski masih sejalan dengan kecenderungan pada judul dan isue, bahwa di tahun 2010 mengalami penurunan. Di tahun 2011, kecenderungan pada pendekatan meningkat. Pada tahap analisa, mulai analisa tapak, bahan dan material, iklim dan kondisi geografis hampir selalu dilakukan. Hal ini mungkin dikarenakan rutinitas kegiatan yang selalu diarahkan ke arah arsitektur nusantara, mulai pembelajaran desain tahap awal hingga akhir. Meski yang sering dilakukan juga oleh mahasiswa, adalah pendekatan tinggal pendekatan. Hasil akhir dan penerapan seringkali mengabaikan pendekatan yang telah dilakukan, hingga sama sekali tidak mempertimbangkan aspek pendekatannya. Rata-rata perkembangan kecenderungan pendekatan/ analisa/ konsep yang telah mengarah pada arsitektur nusantara dari tahun ke tahun dapat dilihat pada tabel berikut ini: 


\section{Tabel 3. Perkembangan Penerapan Arsitekur Nusantara}

Pada Pendekatan Skripsi

\begin{tabular}{|c|c|}
\hline TAHUN & TINGKAT PENERAPAN \\
\hline 2007 & 1,72 \\
\hline 2008 & 2,4 \\
\hline 2009 & 3,29 \\
\hline 2010 & 2,9 \\
\hline 2011 & 3,05 \\
\hline
\end{tabular}

\subsubsection{Penerapan Arsitektur Nusantara}

Pada skripsi berbasis desain, tahap perancangan, merupakan pengembangan konsep-konsep perancangan hasil dari pengamatan dan analisis pada tahap pra rencana menjadi rancangan tapak dan bangunan secara fisik dan dapat diwujudkan. Seringkali pada pengambilan judul, issue, hingga pendekatan sudah mengarah pada arsitektur nusantara, tetapi aplikasinya mahasiswa berjalan seakan memakai 'kacamata kuda ', apa yang telah dilakukan dan dibahas dipertimbangkan di awal pengerjaan skripsi, tetapi pada tahap pra rencana diabaikan begitu saja. Perbedaan penerapan di tahun-tahun sebelum diberlakukannya kurikulum berbasis arsitektur nusantara dengan setelah diberlakukannya kurikulum tersebut tampak perbedaan dan peningkatan yang cukup signifikan. Hal ini membuktikan bahwa, memberikan pemahaman tidak bisa dengan cara instan, tetapi harus terus menerus agar lebih meresap dan melekat pada pemahaman mahasiswa. Contoh penerapan arsitektur nusantara dalam perancangan yaitu pada skripsi berikut ini:

\section{- Pusat Multimedia di Kota Depok}

Inti kajian adalah mewujudkan bangunan pusat multimedia dengan konsep Green Design.

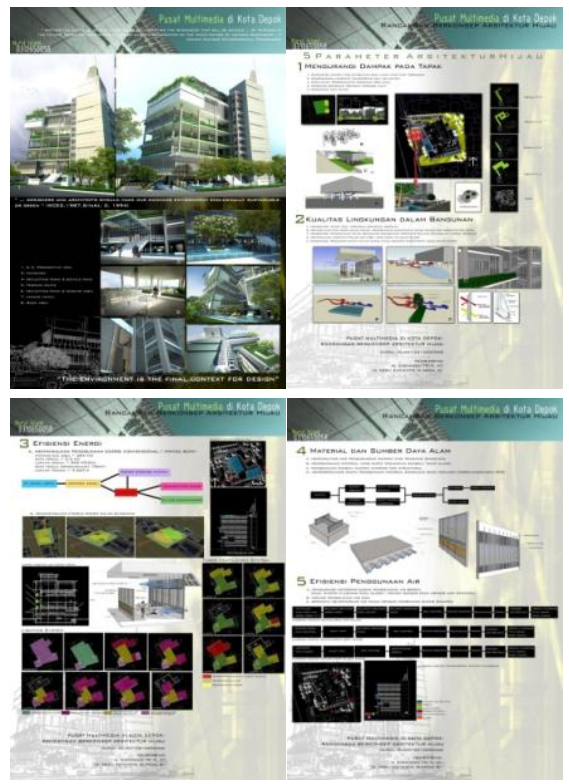

Gambar 2

Contoh penerapan

arsitektur nusantara pada skripsi berjudul Pusat Multimedia di Kota Depok (Sumber: Nurul Islami, 2009) 
Rata-rata perkembangan kecenderungan penerapan yang telah mengarah pada arsitektur nusantara dari tahun ke tahun dapat dilihat pada tabel berikut ini:

Tabel 4. Perkembangan Penerapan Arsitekur Nusantara Pada Judul Skripsi

\begin{tabular}{|c|c|}
\hline TAHUN & TINGKAT PENERAPAN \\
\hline 2007 & 1,22 \\
\hline 2008 & 2,0 \\
\hline 2009 & 2,48 \\
\hline 2010 & 2,3 \\
\hline 2011 & 2,8 \\
\hline
\end{tabular}

(Sumber: Hasil analisis, 2012)

\subsubsection{Konsistensi Penerapan Arsitektur Nusantara}

Meski pada uraian di atas kecenderungan pendekatan sangat baik, tetapi konsistensi terhadap pendekatan sering diabaikan. Pada pengerjaan skripsi, meski pada bab isue pendekatan telah mengarah pada arsitektur nusantara, tetapi hasil akhir atau penerapan hasil desain sering mengabaikan pendekatan yang telah dilakukan. Di samping itu, juga ada permasalahan inkonsistensi dari bab ke bab berikutnya, antara lain;

- Latar belakang kurang mendukung rumusan masalah yang diambil

- Pustaka yang diambil kurang mendukung pada latar belakang dan isue yang diungkapkan

- Metode yang digunakan kurang sesuai dengan tujuan kajian

- Pendekatan dan analisa yang digunakan tidak didukung oleh pustaka yang ada

- Analisa dan pendekatan yang telah dilakukan tidak diterapkan pada perancangannya

Dari skripsi yang ada diperkirakan lebih dari $50 \%$ kurang konsisten dalam pengerjaan skripsinya. Rata-rata perkembangan kecenderungan konsistensi yang telah mengarah pada arsitektur nusantara dari tahun ke tahun dapat dilihat pada tabel berikut ini.

Tabel 5. Perkembangan Penerapan Arsitekur Nusantara Pada Judul Skripsi

\begin{tabular}{|c|c|}
\hline TAHUN & TINGKAT PENERAPAN \\
\hline 2007 & 1,12 \\
\hline 2008 & 2,0 \\
\hline 2009 & 2,57 \\
\hline 2010 & 2,5 \\
\hline 2011 & 2,8 \\
\hline
\end{tabular}

(Sumber: Hasil analisis, 2012)

\subsubsection{Era Setelah Penggunaan Kurikulum Berbasis Arsitektur Nusantara}

Sejak tahun 2011, penerapan arsitektur nusantara cukup baik dan variatif. Mahasiswa lebih kreatif dalam mencari judul dan isue berbasis arsitektur nusantara, demikian juga pada tingkat kedalaman kajian. Dari judul yang diambil, sebagian besar dari mahasiswa telah memahami bahwa arsitektur nusantara merupakan wujud arsitektur yang tidak sekedar dipoles dan dibungkus dengan wajah tradisional, tetapi lebih pada makna dan nilainya. 
Jika dibandingkan dengan produk skripsi ditahun-tahun sebelumnya, perkembangan penggunaan tema arsitektur nusantara lebih membaik. Hal ini dikarenakan sejak mahasiswa masuk dan mengikuti perkuliahan, semua matakuliah mulai diarahkan ke tema arsitektur nusantara. Berikut beberapa contoh penerapan arsitektur nusantara pada karya skripsi mahasiswa di tahun 2011:

\section{- Material Daur Ulang Anorganik pada Elemen Interior Galeri Seni Daur Ulang Anorganik di Surabaya}

Inti kajian adalah pemanfaatan material daur ulang anorganik, karena banyak limbah anorganik di sekitar kita yang diketahui sangat sulit terdaur secara alami.

INTERIOR RUANG PAMER KACA
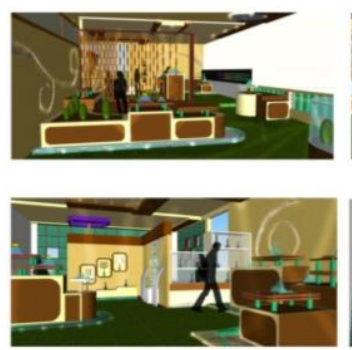
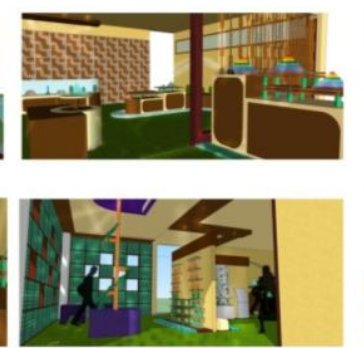

INTERIOR RUANG PAMER PLASTIK
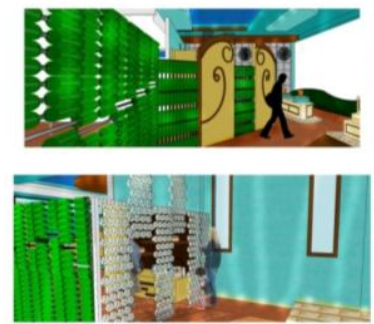

INTERIOR RUANG PAMER KALENG
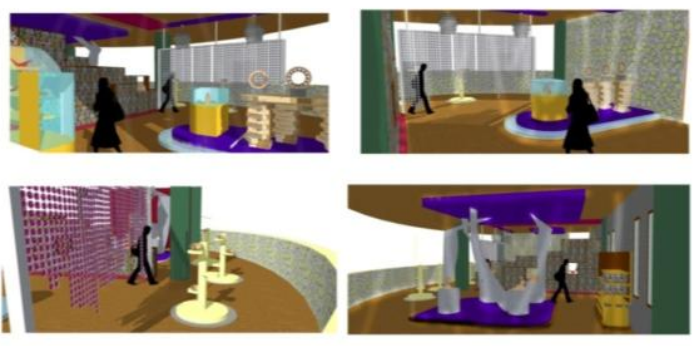
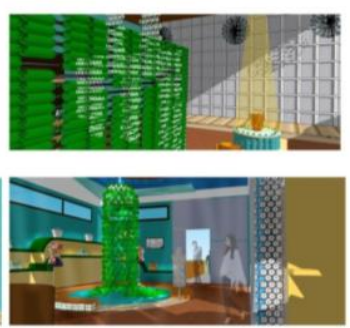

Gambar 4

Penerapan arsitektur nusantara pada skripsi berjudul Material Daur Ulang Anorganik pada Elemen Interior Galeri Seni Daur Ulang Anorganik di Surabaya (Sumber: Widya Rifantri, 2012)

\section{- Agroindustri Jeruk di UPT Simpang Arja Barito Kuala, Kalimantan Selatan dengan Konsep Material Lokal}

Inti kajian adalah pemanfaatan kayu galam sebagai material lokal yang sangat berlimpah, tetapi pemanfaatannya masih sangat minim. Studi pemanfaatan material lokal sebagai elemen fasade bangunan, diharapkan memberikan wacana bagaimana upaya meningkatkan nilai kayu galam tidak hanya sebagai bahan pondasi dan perancah bangunan semata. 

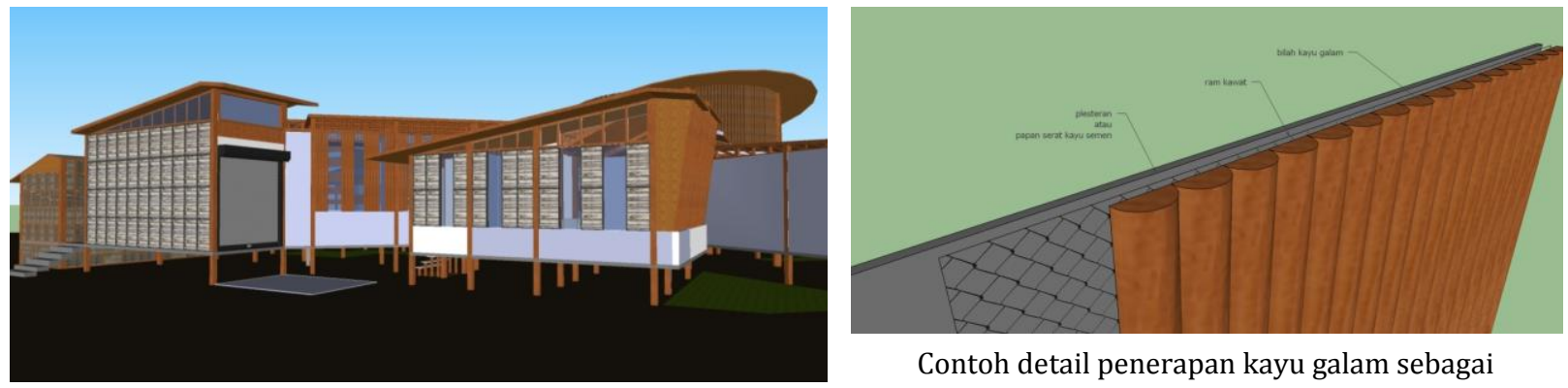

Contoh detail penerapan kayu galam sebagai

Gambar 5

Penerapan arsitektur nusantara pada skripsi berjudul Agroindustri Jeruk di UPT Simpang Arja Barito Kuala, Kalimantan Selatan dengan Konsep Material Lokal (Sumber: Kartika Anggraeni Sudikno Putri, 2012)

Terlepas dari segala kekurangan produk skripsi yang dihasilkan mahasiswa, baik substansi, kedalaman kajian, hingga tata tulis dan sistematika pembahasan, maka tidak bisa dipungkiri bahwa peningkatan tema ke arah arsitektur nusantara mengalami peningkatan secara signifikan.

\section{KESIMPULAN}

Berdasar uraian dan analisa yang telah dilakukan, kesimpulan yang dapat diambil antara lain adalah :

- Perkembangan penggunaan arsitektur nusantara pada skripsi, cukup baik. Meski belum maksimal, tetapi menunjukkan kenaikan yang signifikan.

- Penggunaan tema Arsitektur Nusantara pada implementasi kurikulum, cukup efektif dalam mengarahkan mahasiwa menjadi calon arsitek yang berwawasan nusantara.

- Pada tahap pendekatan, implementasi cukup baik, hanya pada tahap penerapan dinilai masih kurang konsisten dalam penerapannya.

- Konsistensi penerapan arsitektur nusantara, mulai tahap judul, latar belakang, permasalahan, pendekatan hingga penerapan dinilai masih kurang, mahasiswaperlu lebih "istiqomah" dalam penerapannya.

- Ketepatan dalam pemilihan pembimbing sesuai bidang minat dan kajian, membantu mahasiswa dalam pengerjaan dan penyelesaian skripsinya.

- Ketepatan pemilihan laboratorium sesuai substansi, mempengaruhi ketepatan dalam proses pembimbingan, arahan hingga pengujian; baik tahap penentuan penguji maupun arah materi.pengujian.

\section{Daftar Pustaka}

Hardiyati, Pendidikan Arsitektur Berbasis Masyarakat Menuju Masa Depan, Makalah ini disampaikan pada pada Seminar Nasional Pendidikan Arsitektur, Depok 9-10 Desember 2000

Islami, Nurul,2009, Pusat Multimedia di Depok, Bogor. Skripsi, Jurusan Arsitektur, Fakultas TeknikUniversitas Brawijaya, Malang

Manual Prosedur Skripsi Arsitektur, 2011, Jurusan Arsitektur, Fakultas TeknikUniversitas Brawijaya, Malang 
Pangarsa, Galih Widjil, 2008, Bahtera Kemanusiaan Arsitektur Di Laut Karawitan Arsitektur, Makalah ini disampaikan pada Seminar Nasional Ke-Bhinekaan Bentuk Arsitektur Nusantara, Surabaya: 12-13 September 2008

Panduan Penulisan Skripsi (Proposal Skripsi, Skripsi dan Artikel Ilmiah), Fakultas Teknik Universitas Brawijaya, Tahun Akademik 2008

Pedoman Pendidikan Jurusan Arsitektur Fakultas Teknik Universitas Brawijaya, Tahun Akademik 2011/2012-2015/2016

Pitana, Dr. Titis Srimuda, 2010, Diskursus dan Kebhinekaan Makna Atas Arsitektur Nusantara. Makalah ini disampaikan pada Seminar Jelajah Arsitektur Nusantara 2010.

Putri, Diah Kusuma , 2012, Bahan Limbah Mebel Sebagai Elemen Interior Pada Pusat Kerajinan Mebel Kota Malang, Skripsi, Jurusan Arsitektur, Fakultas TeknikUniversitas Brawijaya, Malang

Purbadi, Y Djarot, 2000. Kurikulum Dinamis Menuju Paradigma Baru Pendidikan Arsitektur. Makalah ini disampaikan pada Seminar Pendidikan Arsitektur Meniti Masa Depan, Depok- Jakarta: tanggal 9-10 September 2000.

Rahmawati, Ina Putri , 2012, Galeri Kerajinan Kerang Situbondo (Eksplorasi Material Kerang Pada Limbah Interior Ruang Pamer), Skripsi, Jurusan Arsitektur, Fakultas TeknikUniversitas Brawijaya, Malang

Rifantri, Widya , 2012, Material Daur Ulang Anorganik Pada Elemen Interior Galeri Seni Daur Ulang Anorganik Di Surabaya, Skripsi, Jurusan Arsitektur, Fakultas TeknikUniversitas Brawijaya, Malang

Rudi Yulianto, 2010, Pusat Penelitian \& Pengembangan Energi Listrik Tenaga Laut di Teluk Bakaro Manokwari Papua Barat. Skripsi, Jurusan Arsitektur, Fakultas TeknikUniversitas Brawijaya, Malang

Santoso, Djoko, 2000, Kurikulum Dinamis Menuju Paradigma Baru Pendidikan Arsitektur. Makalah ini disampaikan pada Seminar Pendidikan Arsitektur Meniti Masa Depan, Depok- Jakarta: tanggal 9-10 September 2000.

Sudikno P, Kartika A , 2012, Agroindustri Jeruk di UPT Simpang Arja Barito Kuala, Kalimantan Selatan, Dengan Konsep Material Lokal, Skripsi, Jurusan Arsitektur, Fakultas TeknikUniversitas Brawijaya, Malang

Susanto, Edwien Dwi, 2008, Pasar Agribisnis Batu, Skripsi, Jurusan Arsitektur, Fakultas TeknikUniversitas Brawijaya, Malang

Tribinuka, Tjahja 2008, Pendayagunaan Arsitektur Nusantara Untuk Proses Perancangan Mutakhir. Makalah ini disampaikan pada Seminar Nasional Ke-Bhinekaan Bentuk Arsitektur Nusantara, Surabaya: 12-13 September 2008

Widigdo C, Wanda, 2005, Wawasan Lingkungan Yang Berkelanjutan Pada Pendidikan Arsitektur. Makalah ini disampaikan pada Seminar Nasional Pendidikan Arsitektur, Depok 9-10 Desember 2005

Yudohusodo, 1991, Rumah Untuk Seluruh Rakyat, INKOPPOL, Unit Percetakan Bharakerta, Jakarta 